\title{
Cloning of the Bacillus subtilis lys and spoIIIB Genes in Phage $\phi 105$
}

\author{
By H. F. JENKINSON† AND J. MANDELSTAM* \\ Microbiology Unit, Department of Biochemistry, University of Oxford, Oxford OXI $3 Q U, U . K$.
}

(Received 13 December 1982; Revised 31 January 1983)

\begin{abstract}
The lys gene of Bacillus subtilis was inserted into prophage $\phi 105$. The recombinant phage $(\phi 105 \mathrm{~d} l y s)$ contained DNA which was about $2 \mathrm{MDal}$ smaller than the wild-type phage DNA, and the phage particles had no tails. The phage did not plaque but, when provided with tails in vitro, it transduced both $l y s-1$ and $l y s-3$ strains of $B$. subtilis to Lys ${ }^{+}$. The $l y s^{+}$gene was located on a $2.5 \mathrm{MDal}$ EcoRI restriction fragment. Subsequently this phage was used to clone, using a similar technique, the spoIIIB gene(s). The second recombinant phage, $\phi 105 \mathrm{~d} s p o I I I B$, was also defective, i.e. without tails. The DNA was 1.5 MDal smaller than the wild-type phage DNA and the spoIIIB2+ gene was located on a $3 \mathrm{MDal} E c o \mathrm{RI}$ fragment. When provided with tails in vitro, phage $\phi 105 \mathrm{~d} s p o I I I B$ transduced cells of a spoIIIB 2 recipient to $\mathrm{Spo}^{+}$. In these transductants the spoIIIB2 mutation was complemented, and the cells sporulated normally.
\end{abstract}

\section{INTRODUCTION}

From recent reviews (Young \& Mandelstam, 1979; Piggot et al., 1981) it appears that about 50 genetic loci have now been identified whose expression is required for spore formation and germination in Bacillus subtilis. By cloning the genes in these loci it should be possible (a) to determine what their protein products are and (b) to identify the regulatory molecules which might control their expression. To these ends some significant advances have recently been made using cloned sporulation genes on phage and plasmid vectors. Thus, Hirochika et al. (1981) have identified a protein which might be a product of the spoOB locus, and the forms of RNA polymerase which recognize the known nucleotide sequences of at least two spo genes (Moran et al., 1982) have been identified (Losick \& Pero, 1981).

From the map distances as measured by recombination index between mutations within a locus it appears that several of the spo loci probably contain more than one gene (Coote, 1972; Piggot \& Coote, 1976; Lloyd-Jones, 1976; Yudkin \& Turley, 1981). To determine precisely how many genes each locus contains, complementation analysis is required in conjunction with the genetic mapping. Using a protoplast fusion technique, Dancer \& Mandelstam (1981) have shown by complementation that the spoIVC locus contains at least two cistrons. However this method was successful only with mutants blocked at stage IV and this is obviously a serious limitation. Gene cloning has now made it possible to carry out complementation analysis on other loci. Thus Hirochika et al. (1981) have cloned the $s p o O B^{+}$gene on phage $\rho 11$ and used it to complement mutations in the $s p o O B$ locus. More recently, Liu et al. (1982) have shown, using a cloned region of the spoIIA locus, that this locus probably contains at least two genes.

We decided to clone spo genes using the temperate $B$. subtilis phage $\phi 105$ (Birdsell et al., 1969) which contains DNA of size about $25 \mathrm{MDal}$ and which has been used as a cloning vector for at least one B. subtilis vegetative gene (Iijima et al., 1980). In this paper we describe the cloning of the lys and spoIIIB loci in phage $\phi 105$, and the complementation of the lys-1, lys-3 and spoIIIB 2 mutations by the recombinant phages.

† Present address: Department of Oral Biology, University of Otago, Box 647, Dunedin, New Zealand.

Abbreviations: BHIB, Brain Heart Infusion Broth; TBAB, Tryptose Blood Agar Base. 
Table 1. Strains of B. subtilis used

\begin{tabular}{ll}
$\begin{array}{c}\text { Strain } \\
\text { designation }\end{array}$ & \multicolumn{1}{c}{$\quad$ Genotype } \\
168 & trpC2 \\
MY2016 & hisH2 lys-1 sul ${ }^{\mathrm{R}}$ rif $^{\mathrm{R}}$ \\
CU267 & leuB16 ilvB2 trpC2 \\
SL989 & lys-3 metB10 recE4 \\
MB79 & metC3 pheAI2 \\
SG20 & metC3 lys-3 \\
$1 \mathrm{~L} 11$ & trpC2 $(\phi 105)$ \\
CU267 & leuB16 ilvB2 trpC2 $(\phi 105) \dagger$ \\
89.9 & lys-1 spoVA89 \\
2.3 & lys-1 spoIIIB2 \\
2.5 & rif ${ }^{\mathrm{R}}$ spoIIIB2 \\
165.1 & trpC2 spoIVB165 \\
299 & trpC2 spoOA299 \\
34.4 & lys-I tal-I spoOA34 \\
43.7 & pheA12 spoOA43 \\
26.4 & lys-1 spoIIIA26 \\
59.7 & leuBI6 trpC2 spoIIA59
\end{tabular}

Original isolation no./ source/reference

Laboratory stock

Laboratory stock

S. Zahler

P. Piggot

Laboratory stock

Laboratory stock

BGSC*

Laboratory stock

89; Hranueli et al. (1974)

A3; Piggot (1973)

A3; Piggot (1973)

P7; Coote (1972)

P10; Coote (1972)

$3 \mathrm{~F} 1$; Hranueli et al. (1974)

NG6.21 ; Piggot (1973)

E34; Piggot (1973)

NG14.7; Piggot (1973)

* Bacillus Genetic Stock Center, The Ohio State University, Columbus, Ohio, U.S.A

$\dagger$ This strain was used as the stock lysogen after phage $\phi 105$ was transferred into it from strain $1 \mathrm{~L} 11$. Other strains lysogenic for phage $\phi 105$ referred to in the text were all made from the above strains by plaquing the phage on to a lawn of the strain and picking from the centre of a plaque.

\section{METHODS}

Bacteria. The bacterial strains used are listed in Table 1.

Preparation of phage $\phi 105$ lysates. BHIB (Brain Heart Infusion Broth, Oxoid) containing $0.5 \%(\mathrm{w} / \mathrm{v})$ Yeast Extract (Oxoid; $5 \mathrm{ml}$ ), was inoculated with a fresh colony of a $\phi 105$ lysogen, and the bacteria were grown with shaking at $37^{\circ} \mathrm{C}$ to an $\boldsymbol{A}_{600} \sim 0.4$ (about $2 \times 10^{8} \mathrm{cells} \mathrm{ml}^{-1}$ ). Mitomycin C (Sigma; final concn $0.5 \mu \mathrm{g} \mathrm{ml}^{-1}$ ) was then added, and after 20 min incubation the cells were pelleted by centrifugation, suspended in fresh warm aerated BHIB $(5 \mathrm{ml})$ and shaken for $2 \mathrm{~h}$ by which time lysis had usually occurred. The cell debris was removed by centrifugation $\left(5000 \mathrm{~g}, 5 \mathrm{~min}\right.$ ) and DNAase I (Sigma; final concn $10 \mu \mathrm{g} \mathrm{ml}^{-1}$ ) was added to the supernatant. This was left for $5 \mathrm{~min}$ at $20^{\circ} \mathrm{C}$ and then filtered through a $0.45 \mu \mathrm{m}$ membrane filter and stored at $4{ }^{\circ} \mathrm{C}$ over chloroform $(0.1 \mathrm{ml})$. Such a lysate typically contained $2 \times 10^{9}$ p.f.u. $\mathrm{ml}^{-1}$.

Measurement of phage titre. Phage $\phi 105$ suspension $(0.1 \mathrm{ml})$ was mixed with mid-exponential phase cells of indicator strain CU267 in BHIB $(0.1 \mathrm{ml})$; molten agar $[3 \mathrm{ml}$ of one-third-strength Tryptose Blood Agar Base (TBAB, Difco)] was then added, and the mixture poured on to warm TBAB plates. Plaques were counted after incubating the plates at $30^{\circ} \mathrm{C}$ for $16 \mathrm{~h}$.

Phage $\phi 105$ purification. A culture of strain CU267 (lysogenic for phage $\phi 105)$ in BHIB $(250 \mathrm{ml})$ was grown to a density of about $2 \times 10^{8}$ cells $\mathrm{ml}^{-1}$. Phage were induced with mitomycin $\mathrm{C}$ as above, and the cells suspended in fresh medium and allowed to lyse. To the clarified culture supernatant was added $\mathrm{NaCl}(5.8 \mathrm{~g})$ and polyethylene glycol $6000(22.5 \mathrm{~g})$ (Yamamoto et al., 1970), and these were dissolved by gently agitating the mixture. This was left at $4^{\circ} \mathrm{C}$ for $2 \mathrm{~h}$, and the precipitate was collected by centrifugation $\left(10000 \mathrm{~g}, 20 \mathrm{~min}, 4^{\circ} \mathrm{C}\right)$. The pellet was suspended in phage buffer $\left(3 \mathrm{ml}\right.$, consisting of $10 \mathrm{mM}$-Tris, $\left.100 \mathrm{mM}-\mathrm{NaCl}, 10 \mathrm{mM}-\mathrm{MgSO}_{4} .7 \mathrm{H}_{2} \mathrm{O}, \mathrm{pH} 7.4\right)$ and layered on to the surface of a four-step $\mathrm{CsCl}$ gradient. The gradient was prepared by layering the following solutions of $\mathrm{CsCl}$ in a $13 \times 51 \mathrm{~mm}$ Beckman Ultra-Clear centrifuge tube: density $(\rho) 1.50 \mathrm{~g} \mathrm{ml}^{-1}(1.0 \mathrm{ml})$, $1.46 \mathrm{~g} \mathrm{ml}^{-1}(0.8 \mathrm{ml}), 1.39 \mathrm{~g} \mathrm{ml}^{-1}(0.6 \mathrm{ml})$ and $1.17 \mathrm{~g} \mathrm{ml}^{-1}(0.6 \mathrm{ml})$. The gradient was centrifuged in a Beckman SW50.1 swing-out rotor at $110000 \mathrm{~g}$ for $2.5 \mathrm{~h}$, and the phage band (about three-quarters of the way down the gradient) was removed through the side of the tube with a 19 gauge needle and syringe. The phage suspension (about $0.5 \mathrm{ml}$ ) was then dialysed for $16 \mathrm{~h}$ at $4^{\circ} \mathrm{C}$ against phage buffer $(5 \mathrm{l})$, and the contents of the dialysis tubing were made up to $1 \mathrm{ml}$ with phage buffer containing $0.05 \%(\mathrm{w} / \mathrm{v})$ gelatin for storage at $4{ }^{\circ} \mathrm{C}$.

Phage PBSX purification. Phage PBSX was prepared from strain 168 in a similar way to that described above for phage $\phi 105$. It banded much higher up the gradient (buoyant density of PBSX $=1.375 \mathrm{~g} \mathrm{ml}^{-1}$; Okamoto et al., 1968 a) than did $\phi 105$ (buoyant density about $1.47 \mathrm{~g} \mathrm{ml}^{-1}$ ). Phage PBSX is a defective phage which is carried by $B$. subtilis strain 168 . When induced, e.g. with mitomycin $C$, it packages chromosomal DNA randomly into the phage heads (Okamoto et al., 1968 b). The phage thus provides an easily purified source of chromosomal DNA which appears to be good starting material for cloning (see Hirochika et al., 1981). 
Transduction. Stationary-phage cells in BHIB $(0.5 \mathrm{ml})$ were mixed with phage lysate $(0.1 \mathrm{ml})$ and incubated with shaking at $37^{\circ} \mathrm{C}$ for $30 \mathrm{~min}$. The cells were harvested by centrifugation, washed twice with $10 \mathrm{ml}$ Spizizen's minimal medium containing 0.5\% (w/v) glucose (Anagnostopoulos \& Spizizen, 1961), made to $1 \mathrm{ml}$ in the same medium and $0.1 \mathrm{ml}$ portions were plated on to lactate/glutamate minimal agar (Piggot, 1973) containing appropriate L-amino acid supplements $\left(200 \mu \mathrm{g} \mathrm{ml}^{-1}\right.$ each). Plates were incubated for $2 \mathrm{~d}$ at $37^{\circ} \mathrm{C}$, and transductants were purified by streaking them on lactate/glutamate minimal agar. To select $\mathrm{Spo}^{+}$transductants, $0.1 \mathrm{ml}$ samples were plated on to Schaeffer's agar (Schaeffer et al., 1965) in glass Petri plates which were incubated for $18 \mathrm{~h}$ at $37^{\circ} \mathrm{C}$. The agar was exposed to chloroform vapour for 2 to $5 \mathrm{~h}$ at $55^{\circ} \mathrm{C} \mathrm{(Hoch,} \mathrm{1971)} \mathrm{to} \mathrm{select} \mathrm{against}$ asporogenous (recipient) cells. The plates were then incubated for a further 3 to $4 \mathrm{~d}$ at $37^{\circ} \mathrm{C}$ by which time opaque, brown $\mathrm{Spo}^{+}$colonies appeared on a translucent (recipient) background.

Preparation of phage DNA. Phage $\left(0.4 \mathrm{ml}\right.$, containing $10^{11}$ p.f.u. for $\phi 105$, or a roughly equivalent number of particles for PBSX) were mixed with EDTA $[2 \mu \mathrm{l}$ of a $4 \%(\mathrm{w} / \mathrm{v})$ solution] and SDS [ $5 \mu \mathrm{lof}$ a $20 \%(\mathrm{w} / \mathrm{v})$ solution] and heated at $70{ }^{\circ} \mathrm{C}$ for $5 \mathrm{~min}$. The solution was allowed to cool, and potassium acetate $(50 \mu \mathrm{l}$ of a $5 \mathrm{M}$-solution) was added to precipitate protein and SDS. After allowing the suspension to stand for $30 \mathrm{~min}$ on ice, it was centrifuged for $15 \mathrm{~min}$ (in a Beckman microfuge). The supernatant was decanted into a fresh sterile microtube, and $95 \%(\mathrm{v} / \mathrm{v})$ ethanol $(1 \mathrm{ml})$ was added at room temperature to precipitate DNA. The phage DNA was immediately picked out with a fine plastic tip and redissolved in Tris/EDTA buffer (10 mM-Tris, 1 mM-EDTA, pH 7.4; $0.3 \mathrm{ml})$. Alternatively, if the DNA was not visible as a clump, the mixture was centrifuged ( $1 \mathrm{~min}$, in a microfuge), the pellet was drained, the inside of the tube dried, and Tris/EDTA buffer was added to dissolve the pellet.

Preparation of DNA from bacteria. Cell DNA for constructing strains and for mapping was prepared as described by Ward \& Zahler (1973), except that $5 \mathrm{ml}$ of culture was used and the final volume of the DNA solution was $1.5 \mathrm{ml}$.

Transformation. Transformation of competent cells was done by the method of Anagnostopoulos \& Spizizen (1961) as described by Jenkinson (1983). Transformants were plated on lactate/glutamate minimal agar with appropriate supplements, unless selection was for $\mathrm{Spo}^{+}$transformants, when Schaeffer's medium in glass plates was used as described above. When DNA from an agarose gel was used in transformation, rifampin (final concn $2.5 \mu \mathrm{g} \mathrm{ml}^{-1}$ ) was included in the agar to prevent growth of contaminants from the agarose.

Restriction enzymes. These were obtained from BRL, and the buffers used were those recommended by BRL. Double digests using $E c o$ RI and $X b a \mathrm{I}$ were carried out in $E c o$ RI buffer. For double digests with $K p n \mathrm{I}$ and $E c o$ RI, $K p n I$ (in KpnI buffer) was used first and then the buffer components of the mixture were adjusted before adding EcoRI. Digestions were performed at a concentration of 1 or 2 units of enzyme $(\mu \mathrm{g} \mathrm{DNA})^{-1}$ for $3 \mathrm{~h}$ at $37^{\circ} \mathrm{C}$, and they were terminated by treatment at $65^{\circ} \mathrm{C}$ for $20 \mathrm{~min}$.

Ligation. Phage $\phi 105$ DNA, digested with Sau3A, or EcoRI $(10 \mu \mathrm{g}$ DNA in $0.25 \mathrm{ml})$ was mixed with an equal volume of PBSX DNA ( 20 to $30 \mu \mathrm{g}$ in $0.25 \mathrm{ml}$ ) digested with the appropriate enzyme and the mix ture was cooled to $4{ }^{\circ} \mathrm{C}$. Freshly prepared ligase buffer $\left[0.5 \mathrm{ml}\right.$, containing $120 \mathrm{~mm}$-Tris, $20 \mathrm{mM}-\mathrm{MgCl}_{2}, 20 \mathrm{~mm}$-dithiothreitol, $0.2 \mathrm{~mm}$ ATP (sodium salt), pH 7.5] was then added, mixed by inversion, and followed by 5 units of T4 DNA ligase. The ligation was carried out at $15^{\circ} \mathrm{C}$ for at least $16 \mathrm{~h}$, and before using the DNA the ligation was checked by agarose gel electrophoresis.

Electrophoresis of DNA. For separation of DNA fragments, samples were made to $6.5 \%(\mathrm{w} / \mathrm{v})$ in Ficoll (Sigma) and $0.001 \%$ in bromophenol blue, and loaded into the wells formed in a horizontal $0.7 \%$ or $0.8 \%$ agarose gel submerged in gel buffer ( $40 \mathrm{~mm}$-Tris, $18 \mathrm{~mm}$-acetic acid, $2 \mathrm{~mm}$-EDTA, pH $8 \cdot 1)$. Fragments too small to be separated efficiently in agarose were electrophoresed in polyacrylamide gels $(5 \%, \mathrm{w} / \mathrm{v})$ in a vertical apparatus, using the same buffer as above. Gels were stained with ethidium bromide $\left(1 \mu \mathrm{g} \mathrm{ml}^{-1}\right)$ and visualized on a UV transilluminator.

Induction of sporulation. Cells were induced to sporulate by the resuspension method of Sterlini \& Mandelstam (1969).

Measurement of sporulation marker events. Alkaline phosphatase was assayed as described by Glenn \& Mandelstam (1971) using Tris/ $\mathrm{HCl}$ buffer (1 $\mathrm{M}, \mathrm{pH}$ 8). Glucose dehydrogenase activity was measured as described by Sadoff (1966). The numbers of spores surviving treatment with heat or with lysozyme were estimated as described by Jenkinson et al. (1980).

Chemicals. Acrylamide was obtained from BDH, and all other chemicals, unless stated, were from Sigma.

\section{RESULTS}

\section{Isolation of phage $\phi 105 \mathrm{dlys}$}

To try to isolate specialized transducing phage $\phi 105$ carrying the lys gene of $B$. subtilis (and possibly other closely linked sporulation genes in the spoVA or spoIIA loci), the prophage transformation method described by Kawamura et al. (1981) was used. For this, DNA from phage $\phi 105$ (about $10 \mu \mathrm{g}$ ), partially digested with SauIIIA enzyme, was mixed (see Methods) 
with PBSX DNA ( $20 \mu \mathrm{g}$, partially digested with SauIIIA to give fragments mainly of size 3 to $7 \mathrm{MDal})$, ligated and used to transform competent cells $\left(1 \times 10^{8} \mathrm{cells} \mathrm{ml}^{-1}\right)$ of strain MY2016 hisH2 lys-1 $(\phi 105)$ to $\mathrm{Lys}^{+}$. Transformants (112 in total were obtained) were picked on to lactate/glutamate minimal agar containing L-histidine and grown for $18 \mathrm{~h}$ at $37^{\circ} \mathrm{C}$. It was expected that most of these colonies would be true transformants in which the original lys-1 mutation had been lost by homologous recombination. However, some might have become phenotypically $\mathrm{Lys}^{+}$through complementation of $l y s-1$ by $l y s^{+}$integrated into the resident prophage.

Complemented strains, if present, would be a possible source of transducing phages carrying the $l y s^{+}$gene. Accordingly, the 112 colonies were pooled in BHIB $(10 \mathrm{ml})$, phage was induced with mitomycin $C$ (see Methods) and a lysate was obtained which had a titre of $1.5 \times 10^{9}$ p.f.u. $\mathrm{ml}^{-1}$. This was then used to transduce strain MY2016 lys-1 (non-lysogenic for $\phi 105$ ) to Lys ${ }^{+}$. Lys $^{+}$colonies appeared at a frequency of about $2 \times 10^{5}$ per $\mathrm{ml}$ of transduced culture. Five of these transductants were picked and found to be immune to superinfection by phage $\phi 105$. They were therefore assumed to have been lysogenized by $\phi 105$ carrying $l y s^{+}$. However, when lysates were prepared from them and used in turn to transduce strain MY2016 to Lys ${ }^{+}$, no transductants were obtained. Furthermore, the lysates had no plaque-forming activity.

Since each of the five $\mathrm{Lys}^{+}$transductants picked was immune to superinfection, it was reasonable to assume that they contained phage which was defective in either induction or infection. To determine whether these lysates did, in fact, contain phage that required plaqueforming phage as helper to transduce, lysate $(0 \cdot 1 \mathrm{ml})$ made from one of the five transductants was mixed with wild-type phage $\phi 105$ lysate $\left(0.1 \mathrm{ml}, 1 \times 10^{8}\right.$ p.f.u.). The mixture was used to transduce stationary-phage cells of strain MY2016 (0.5 ml, $1 \times 10^{9}$ c.f.u. $)$ to Lys ${ }^{+}$, and $7.2 \times 10^{3}$ Lys $^{+}$transductants $\mathrm{ml}^{-1}$ were obtained. The number of transductants depended upon the amount of wild-type phage lysate added, none being obtained when the wild-type phage alone was used. Thus, the high numbers of transductants obtained previously, using the lysate prepared from the initial transformants, must have been due to the presence in the lysate of wildtype phage.

One Lys ${ }^{+}$transductant was purified, designated strain SG18, and after induction of the cells with mitomycin $\mathrm{C}$, phage were prepared by $\mathrm{CsCl}$ gradient centrifugation. Only one phage band was visible at the bottom of the gradient (PBSX phage is always induced and it forms a band at the top of the gradient) and this had a higher density than the wild-type phage $\phi 105$ (about $1.50 \mathrm{~g} \mathrm{ml}^{-1}$ compared with about $1.47 \mathrm{~g} \mathrm{ml}^{-1}$ for wild-type phage). Electron microscopic observation of the phage in this band showed that only phage heads were present, and no tails were visible. This defective recombinant phage which carried the lys gene was denoted $\phi 105 \mathrm{~d} l y s$.

\section{Nature of the helper activity}

These results suggested that the inability of phage $\phi 105 \mathrm{~d} l y s$ to transduce Lys ${ }^{-}$cells to Lys ${ }^{+}$ may have been due to the lack of functional tails. This seemed more probable when it was found that vortex-mixing of the wild-type phage for several minutes before using it as helper in transduction increased the number of Lys ${ }^{+}$transductants obtained even though it decreased the number of p.f.u. (results not shown). To check, therefore, that the helper activity was not just due to the addition of infectious particles, wild-type phage $\phi 105$ suspension in phage buffer $(1 \mathrm{ml}$, $3 \times 10^{10}$ p.f.u.) was vortex-mixed for $3 \mathrm{~min}$ to remove tails, layered on to $\mathrm{CsCl}(2 \mathrm{ml}$, density $1.39 \mathrm{~g} \mathrm{ml}^{-1}$ ) and then centrifuged at $110000 \mathrm{~g}$ (Beckman SW50.1 rotor) for $3 \mathrm{~h}$. It was assumed that under these conditions intact phage would collect almost at the bottom of the tube while any free tails would remain at the diffuse region between the $\mathrm{CsCl}$ solution and phage buffer. After centrifugation, fractions $(0.5 \mathrm{ml})$ were removed from the tube and assayed for (a) plaqueforming and (b) helper activities. Helper activity was almost completely confined to the fraction containing the tails and this fraction had less than $0.1 \%$ of the total plaque-forming activity (Fig. 1). On the other hand, virtually no helper activity was associated with the plaque-forming phage (Fig. 1). Thus the helper activity in wild-type phage $\phi 105$ lysates could be attributed to the presence of free tails which presumably assemble in vitro on to the $\phi 105 \mathrm{~d} l y s$ phage, enabling it to infect cells. 


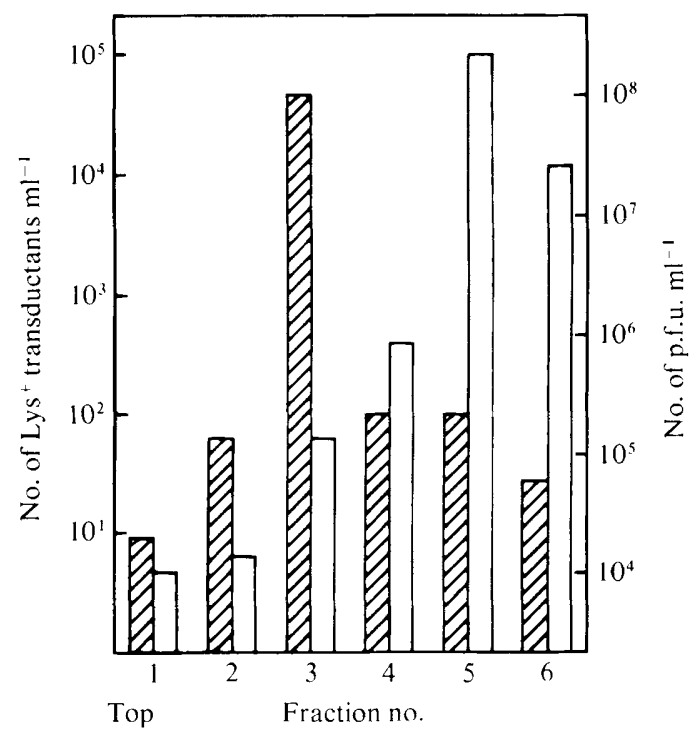

Fig. 1. Plaque-forming and helper activities of wild-type phage $\phi 105$ after centrifugation of vortexmixed phage through $\mathrm{CsCl}$. Phage $\phi 105$ was vortex-mixed for $3 \mathrm{~min}$ to remove tails, and $1 \mathrm{ml}$ of suspension was layered on to the surface of $\mathrm{CsCl}\left(2 \mathrm{ml}\right.$; density $\left.1.39 \mathrm{~g} \mathrm{ml}^{-1}\right)$. After centrifugation (30000 r.p.m., 3 h, Beckman SW 50.1), fractions $(0.5 \mathrm{ml})$ were removed from the tube and assayed for plaque-forming (open blocks) and helper (hatched blocks) activities. The plaque-forming activity was measured as described in Methods using strain CU267 as host. Helper activity was measured by mixing $0.01 \mathrm{ml}$ of each fraction with $0.05 \mathrm{ml}$ phage $\phi 105 \mathrm{~d} / \mathrm{ys}$ lysate prepared from strain SG 18 , and using this to transduce strain MY2016 (his H2 lys-1) to Lys+. Varying the time of pre-incubation of $\mathrm{CsCl}$ sample with phage $\phi 105 \mathrm{~d} l y s$ from 5 to $60 \mathrm{~min}$ did not seem to affect significantly the numbers of transductants obtained. Fraction 3 corresponds to the region at the top of the $\mathrm{CsCl}$ where phage tails are concentrated.

\section{Complementation of lys-1 and lys-3 mutations}

It was obviously necessary to check that the Lys ${ }^{+}$transductants of strain MY2016 arose through complementation of the lys- 1 mutation and not through recombination in the lys region of the chromosome. The simplest way of doing this was to show by transformation that these transductants, though phenotypically $\mathrm{Lys}^{+}$, still contained the lys- 1 mutation. Accordingly, DNA was prepared from five of the transductants and each preparation was used to transform strain MB79 (metC3 pheA12) to $\mathrm{Met}^{+}$. In an experiment of this type up to $5 \%$ of the $\mathrm{Met}^{+}$ transformants should also have acquired the $l y s-1$ mutation by congression (Nester et al., 1963). Transformants (100 from each transformation) were picked and scored separately for congression of lys and phe $e^{+}$(since this latter allele from the $\mathrm{Phe}^{+}$donor DNA should also be transferred at a similar frequency). The expected results were obtained for all five of the DNA preparations; that is between two and six of the $\mathrm{Met}^{+}$transformants were $\mathrm{Lys}^{-}$, and between two and six were $\mathrm{Phe}^{+}$. This confirmed that the original lys-1 mutation was present in $\mathrm{Lys}^{+}$ transductants and had not been lost by recombination.

To determine whether phage $\phi 105 \mathrm{~d} l y s$ also complemented the $l y s-3$ mutation, strain SL989 (lys-3 metB10 recE4) was used as a recipient in transduction. This strain carries, in addition to lys-3, the recE4 mutation (Dubnau et al., 1973) which prevents homologous recombination from occurring. Stationary-phase cells $(0.5 \mathrm{ml})$ of strain SL 989 were mixed with phage $\phi 105 \mathrm{~d} l y$ s lysate $(0.1 \mathrm{ml})$ and wild-type $\phi 105$ helper phage $\left(4 \times 10^{7}\right.$ p.f.u. $)$, and after selection was rinade on lactate/glutamate minimal agar containing L-methionine, $6.3 \times 10^{2} \mathrm{Lys}^{+}$transductants $\mathrm{ml}^{-1}$ were obtained. Since the recipient strain SL989 was recombination-deficient, the Lys ${ }^{+}$ transductants could only have arisen by complementation of the lys-3 mutation.

The spoVA locus is close to lys (Piggot \& Coote, 1976) and therefore it was possible that phage $\phi 105 \mathrm{~d} l y s$ might also have carried the sporulation genes in this locus. The phage was used in an 


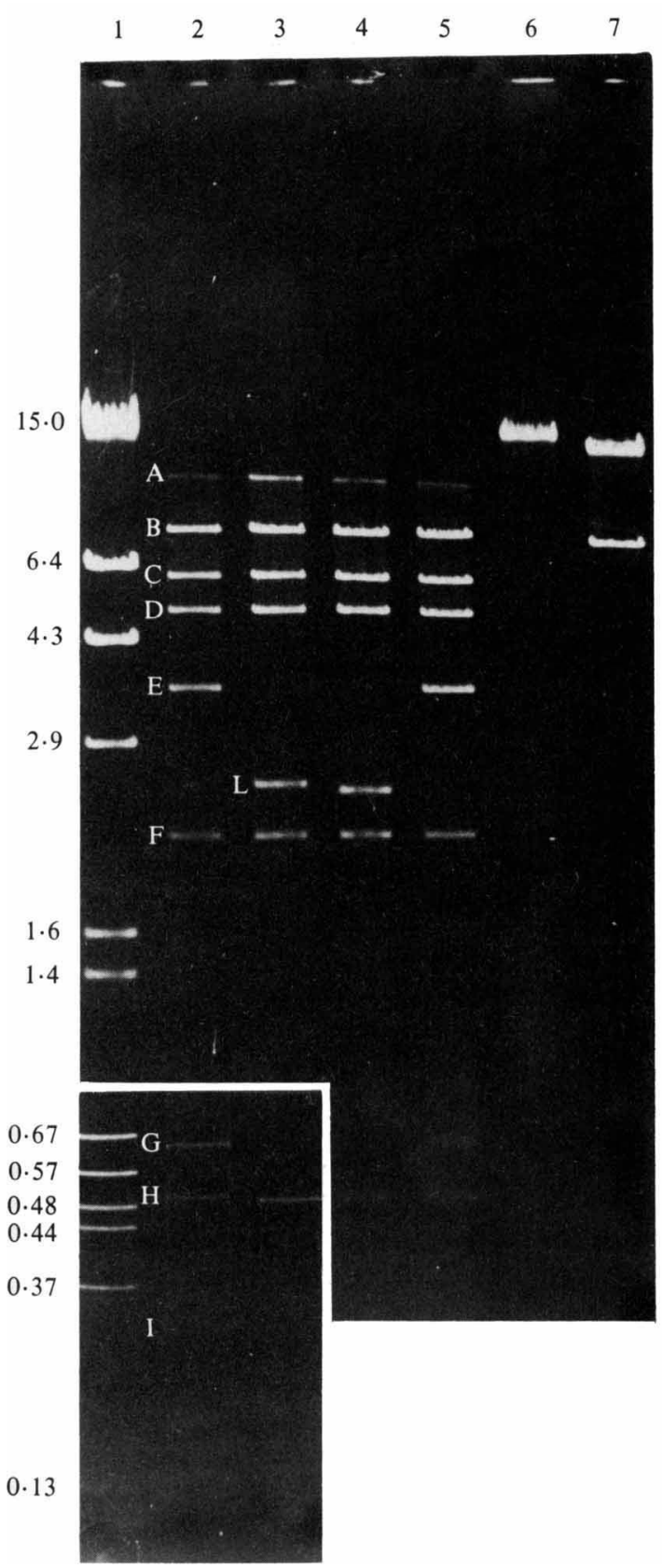

Fig. 2

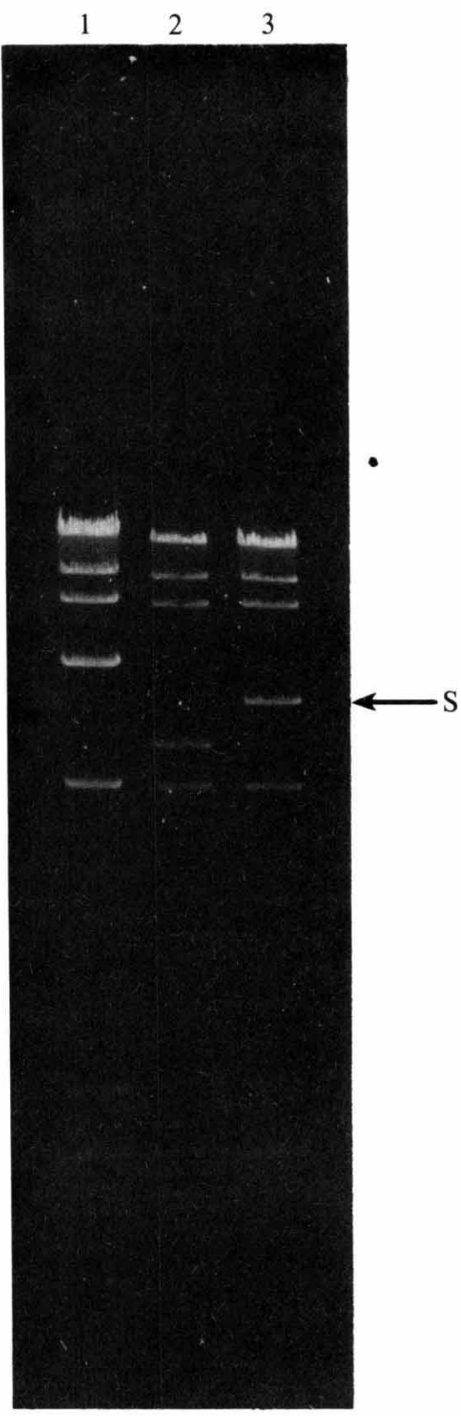

Fig. 3

Fig. 2. Restriction endonuclease analysis of phage $\phi 105$ DNA and phage $\phi 105 \mathrm{~d} l y s$ DNA using EcoRI and $\mathrm{XbaI}$. The figure is a composite of two gels: the upper $(0.8 \%$ agarose) gel shows $E c o$ RI fragments A to $\mathrm{F}$ (see text); the lower inset ( $5 \%$ polyacrylamide) gel shows fragments $\mathrm{G}, \mathrm{H}$ and $\mathrm{I}$. Both gels were stained with ethidium bromide. Lane 1, molecular weight standards with fragment sizes given in MDal [upper gel, phage $\lambda$ HindIII fragments; lower gel, Staphylococcus aureus Imp 18 plasmid (kindly provided by K. G. H. Dyke) HinfI fragments]; lane 2, $\phi 105$ digested with EcoRI; lane 3, $\phi 105 \mathrm{~d} l y s$ with $E c o$ RI ; lane 4, $\phi 105$ dlys with EcoRI plus $X b a \mathrm{I}$; lane 5, $\phi 105$ with $E c o$ RI plus $X b a \mathrm{I}$; lane 6, $\phi 105$ with $X b a \mathrm{I}$; lane 7, $\phi 105 \mathrm{~d} l y s$ with $X b a \mathrm{I}$.

Fig. 3. Agarose gel electrophoresis $(0 \cdot 8 \%$ agarose) of the fragments obtained after EcoRI digestion of DNA from phage $\phi 105$ (lane 1), $\phi 105 \mathrm{~d} l y s$ (lane 2) and $\phi 105 \mathrm{~d}$ spoIIIB (lane 3). 
attempt to transduce strain 89.9 (lys-1 spoVA89) to $\mathrm{Spo}^{+}$, but no $\mathrm{Spo}^{+}$transductants were obtained. This result, however, does not show definitively that phage $\phi 105 \mathrm{~d} l y s$ does not carry spoVA89+ because the spo- 89 mutation might be dominant. Therefore, in another experiment, DNA was prepared from the phage and used to transform strain 89.9 to Lys ${ }^{+}$. The mutation spo89 is about $60 \%$ linked by transformation to $l y s-l$ (unpublished results), so if phage $\phi 105 \mathrm{~d} l y s$ carried $s p o-89^{+}$then approximately $60 \%$ of the Lys ${ }^{+}$transformants would be expected to be $\mathrm{Spo}^{+}$. In fact, out of $5.3 \times 10^{3}$ transformants obtained, none was $\mathrm{Spo}^{+}$, showing that the phage did not carry that part of the spoVA locus defined by the mutation spo- 89 .

Restriction endonuclease mapping of $\phi 105$ wild-type and $\phi 105$ dlys DNAs

Phage $\phi 105$ DNA has been shown by Perkins et al. (1978) and by Scher et al. (1978) to be cleaved into nine fragments by the enzyme EcoRI. These were arranged in a linear map by Perkins et al. (1978) and lettered B to J. This convention has been retained in this paper and Fig. 2 (lane 2) shows the fragments obtained after digestion of wild-type phage DNA with EcoRI. Band $\mathrm{A}$ is the sum of fragments $\mathrm{C}$ and $\mathrm{D}$ which have partially annealed owing to their sticky ends (Perkins et al., 1978).

Fragment J (about 0.2 MDal) of Scher et al. (1978) does not appear in the digest, and absence of this band was also noted by lijima et al. (1980). When $\phi 105 \mathrm{~d} l y s$ DNA was cleaved with EcoRI, the 3.6 MDal, 0.62 MDal and 0.26 MDal fragments (E, G and I bands) were missing, and one new fragment (2.5 MDal appeared (denoted band L in Fig. 2, lane 3). The sum of the molecular weights of the $E c o$ RI fragments obtained from wild-type phage DNA was $25 \cdot 1 \mathrm{MDal}$; the sum of the fragments from $\phi 105 \mathrm{~d} l y s$ DNA was $23 \cdot 1 \mathrm{MDal}$.

To show that fragment $\mathrm{L}$ contained the lys gene, $\phi 105 \mathrm{~d} l y s$ DNA $(1 \mu \mathrm{g})$ was digested with $E c o$ RI, the fragments were separated by agarose gel electrophoresis, and band L was excised from the partially stained gel. When homogenized in transformation medium and mixed with competent cells of strain MY2016 ( $1 \mathrm{ml}$, about $1 \times 10^{8}$ c.f.u. $), 5 \cdot 2 \times 10^{4} \mathrm{Lys}^{+}$transformants $\mathrm{ml}^{-1}$ were obtained. No more than $20 \mathrm{Lys}^{+}$colonies $\mathrm{ml}^{-1}$ were obtained using any other of the EcoRI fragments.

Phage $\phi 105$ DNA has no sites for the enzymes BamHI (Iijima et al., 1980), BglII, XbaI, XhoI or SstII. However, one of these enzymes, $X b a \mathrm{I}$, cut $\phi 105 \mathrm{~d} l y s$ DNA at a single site, giving two fragments of sizes 7.2 MDal and 15.8 MDal (Fig. 2, lane 7). This single new Xbal site must reside in fragment $\mathrm{L}$, and to show this, $\phi 105 \mathrm{~d} l y s$ DNA was digested with both $X b a \mathrm{I}$ and $E c o$ RI. This resulted in the reduction in size of band $\mathrm{L}$ from 2.5MDal to about 2.4 MDal (Fig. 2, lane 4). Since the smaller of the two fragments generated by single digestion with $X b a$ I was $7 \cdot 2 \mathrm{MDal}$, this result indicates that the $X b a \mathrm{I}$ site is within fragment $\mathrm{L}$ and to the right hand side of it (Fig. 4).

Several other restriction enzymes were used to try to construct a simple restriction map of the phages, but PvuII, PstI, HindIII and HincII (each of which recognizes a hexanucleotide sequence) cut the DNA at more than eight sites. However, the enzyme KpnI which cut the DNA of the wild-type phage into four fragments (gel not shown), cut $\phi 105 \mathrm{~d} l y s$ DNA into only three. The deleted region in the wild-type phage thus contained a $K p n I$ site. The results obtained with single and double digests of $K p n \mathrm{I}$ and $E c o$ RI position the $K p n \mathrm{I}$ sites in the wild-type and dlys phage DNAs as shown in Fig. 4.

\section{Orientation of lys- $1^{+}$and lys- $3^{+}$on $\phi 105$ dlys DNA}

In order to see if treatment with $X b a \mathrm{I}$ reduced $\mathrm{Lys}^{+}$transforming activity of the dlys phage DNA (i.e. whether or not the $X b a \mathrm{I}$ site was close to or within the lys gene), the DNA was treated with $X b a I$ and $E c o$ RI, or with $E c o$ RI or left untreated, and used to transform competent cells of either strain MY2016 lys-1 or strain SG20 lys-3, to Lys ${ }^{+}$. With the latter as recipient, treatment of the phage DNA with either EcoRI alone, or with EcoRI and $X b a \mathrm{I}$ together, reduced the number of Lys $^{+}$transformants obtained to about $10 \%$ of the number obtained using the control (unrestricted) DNA (Table 2). However, with MY2016 (lys- I) as recipient, treatment of the DNA with EcoRI reduced the transforming activity to about $3 \%$, and treatment with both enzymes reduced this further to about $1 \%$ of the unrestricted DNA value (Table 2). These results are taken to indicate that $l y s-1$ is closer to the Eco RI site at the right-hand end of fragment L than 


\section{Table 2. Effect of EcoRI and XbaI treatment on the transforming activity of phage $\phi 105$ dlys DNA}

Phage DNA $(1 \mu \mathrm{g})$ was incubated with enzyme or left untreated and then used to transform strain MY2016 or strain SG20 to Lys ${ }^{+}$.

\author{
DNA incubated \\ with:

Nothing
EcoRI
$X b a \mathrm{I}+E c o$ RI

$\overbrace{\begin{array}{c}\text { Recipient MY2016 } \\ \left.\text { (selection for lys-1 } 1^{+}\right)\end{array}}^{\text {No. of } \text { Lys }^{+} \text {transformants } \mathrm{ml}^{-1}}$

is lys-3 (Fig. 4), because the closer a marker is to the end of a transforming fragment, the less likely it is to transform. Thus, since $X b a I$ treatment reduces further the transforming activity of lys- $I^{+}$but not of $l y s-3^{+}$, treatment with $X b a$ I must bring $l y s-1$ even closer to the end of fragment $\mathrm{L}$ (Fig. 4).

\section{Cloning of spoIIIB gene(s) using $\phi 105$ dlys}

The introduction of the lys gene into phage $\phi 105$ generated a phage that might be considered useful as a general vector for cloning homologous DNA in B. subtilis. This is because (1) the phage DNA was about $2 \mathrm{MDal}$ smaller than that of the wild-type phage, and (2) a single restriction site was introduced into a sequence that is not essential for the phage. On this basis, it should be possible to clone an additional fragment of DNA up to $2 \mathrm{MDal}$ in size into the $X b a \mathrm{I}$ site, transfect cells of a suitable recipient and then to select transducing phage carrying the gene which it is intended to clone. However, $\phi 105$ DNA is poorly infectious (Flock \& Rutberg, 1974) since it is degraded during transfection, and $X b a I$ was found to cut PBSX DNA slowly and incompletely. For these reasons, and because we had been unsuccessful on a number of occasions with $\phi 105$ wild-type phage, we attempted to use $\phi 105 \mathrm{~d} l y s$ as a starting point to clone spo genes by the technique of prophage transformation described above. From a number of $\mathrm{Spo}^{-}$ recipient strains tried in transformations, a recombinant phage was purified which complemented the spo-2 mutation in the spoIIIB locus.

The details of the method are as follows. DNA preparations from $\phi 105 \mathrm{~d} l y s(10 \mu \mathrm{g})$ and from PBSX $(20 \mu \mathrm{g})$ were cleaved with $E c o$ RI, ligated (see Methods) and added to a culture $(1 \mathrm{ml}, 1 \times$ $10^{8}$ c.f.u.) containing competent cells of strain 2.3 (spoIIIB2) which were lysogenic for $\phi 105 \mathrm{~d} l y s$. $\mathrm{Spo}^{+}$transformants were selected and the total number obtained (156) were picked on to nutrient agar, grown at $37^{\circ} \mathrm{C}$ for $16 \mathrm{~h}$ and the colonies pooled in BHIB $(10 \mathrm{ml})$. Phage were induced with mitomycin $\mathrm{C}$, and the lysate $(0 \cdot 1 \mathrm{ml})$, mixed with wild-type phage lysate as helper $\left(0.05 \mathrm{ml}\right.$, about $5 \times 10^{7}$ p.f.u. $)$, was used to transduce cells of strain 2.3 spoIIIB 2 to $\mathrm{Spo}^{+}$. Approximately $350 \mathrm{Spo}^{+}$transductants were obtained, and several of these were streaked onto lactate/glutamate minimal agar.

One of these transductants was purified, designated strain 2.4, and phage were prepared from this strain by mytomycin $\mathrm{C}$ induction and $\mathrm{CsCl}$ gradient centrifugation. The phage formed a single band in the gradient and the phage from this band transduced strain 2.3 lys- 1 spoIIIB 2 to $\mathrm{Spo}^{+}$, provided that tails of helper phage were added as described previously. The phage failed to transduce this strain to $\mathrm{Lys}^{+}$, or to transduce strain SG20 (lys-3) to Lys ${ }^{+}$, so it appeared that the lys gene had been inactivated or lost.

To check that the $\mathrm{Spo}^{+}$transductants contained the original spo mutation several of them were picked, DNA was prepared from each of them and this was used to transform strain MB79 to $\mathrm{Phe}^{+}$. For reasons already given, one would expect that 2 to $5 \%$ of the $\mathrm{Phe}^{+}$transformants should be $\mathrm{Spo}^{-}$. In one transformation 3\% (48/1600) of the $\mathrm{Phe}^{+}$transformants were $\mathrm{Spo}^{-}$, and in another $2 \cdot 2 \%(44 / 2020)$ were $\mathrm{Spo}^{-}$, showing that the $\mathrm{Spo}^{+}$transductants carried the original spo- 2 mutation. The recombinant phage carrying spoIIIB was denoted $\phi 105 \mathrm{~d} s p o I I I B$. 


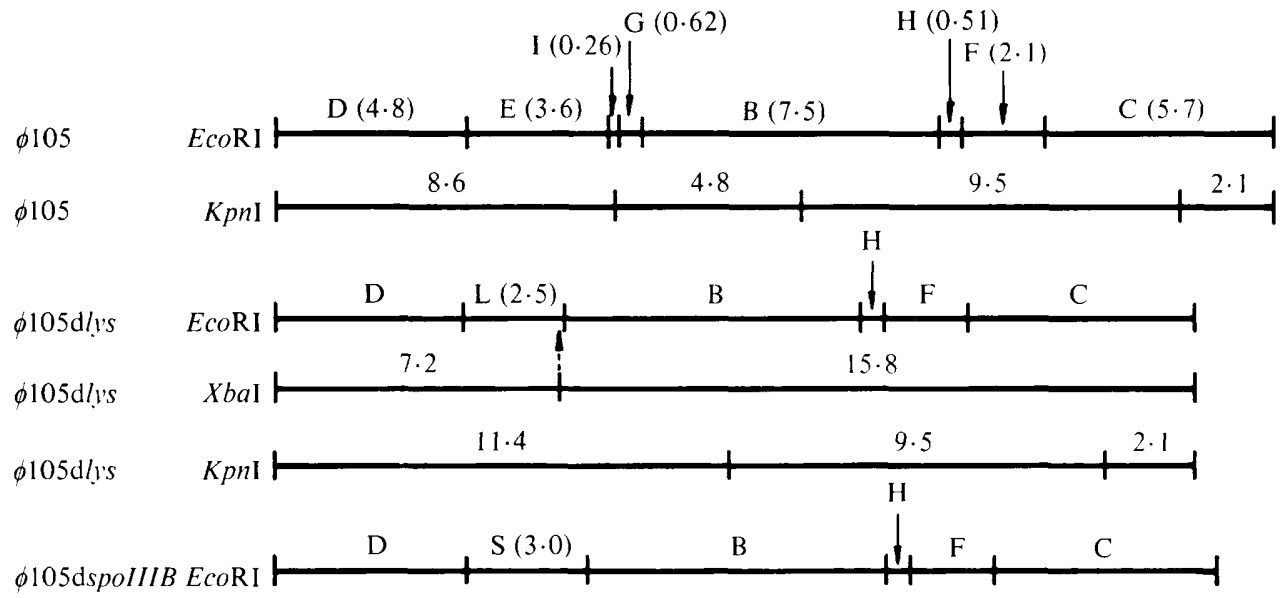

Fig. 4. Restriction endonuclease cleavage maps of DNA from phage $\phi 105$, phage $\phi 105 \mathrm{~d} l y s$ and phage $\phi 105 \mathrm{~d} s p o I I I B$ digested with $E c o \mathrm{RI}, X b a \mathrm{I}$ or $K p n \mathrm{I}$. The sizes of the fragments are in MDal, and they are lettered for identification (see Fig. 2 and text). The EcoRI fragment order of phage $\phi 105$ DNA is from Perkins et al. (1978).

\section{Phenotypic properties of strain $2.4(\phi 105 d$ spoIIIB $)$}

The complemented mutant strain 2.4 was found to sporulate normally, producing the wildtype $\left(\mathrm{Spo}^{+}\right)$amount of glucose dehydrogenase and the wild-type number of heat-resistant and lysozyme-resistant spores at $t_{10}\left(3.2 \times 10^{8}\right.$ spores $\left.\mathrm{ml}^{-1}\right)$. The original spoIIIB strain (2.3) produced no glucose dehydrogenase (Piggot, 1973) and it formed only about $3 \times 10^{5}$ spores $\mathrm{ml}^{-1}$ at $t_{10}$.

\section{Restriction endonuclease analysis of $\phi 105 d$ spoIIIB DNA}

The EcoRI digest pattern of DNA extracted from the spoIIIB $B^{+}$-transducing phage differed from the $\phi 105 \mathrm{~d} l y s$ DNA (Fig. 3, lanes 2 and 3) in that fragment $L$ had been lost and replaced by a new fragment of $3 \mathrm{MDal}$, denoted S. The sum total of the EcoRI fragments was $23.6 \mathrm{MDal}$; thus the $\phi 105 \mathrm{~d}$ spoIIIB phage DNA was still smaller than that in the original wild-type phage by about 1.5 MDal. No new single restriction site was generated in the recombination, e.g. BamHI and $B g l \mathrm{II}$ still did not cut the DNA, and furthermore the $X b a \mathrm{I}$ site was lost (results not shown). The EcoRI restriction map of $\phi 105 \mathrm{~d}$ spoIIIB DNA is shown in Fig. 4.

\section{Transforming activity of $\phi 105 d$ spoIIIB DNA}

The DNA extracted from the phage transformed strain 2.3 lys-1 spoIIIB 2 to $\mathrm{Spo}^{+}$(as would be expected from the transduction results), but not to Lys ${ }^{+}$. Neither did the DNA transform strain SG20 (lys-3) to Lys ${ }^{+}$, showing that the lys gene had been lost. The $\mathrm{Spo}^{+}$transforming activity was located in EcoRI fragment S (Table 3), since only this band, when excised from a partially stained agarose gel, transformed strain 2.5 rif $^{\mathrm{R}}$ spoIIIB2 with high frequency to $\mathrm{Spo}^{+}$. The high background numbers of $\mathrm{Spo}^{+}$colonies in Table 3 were due to some overloading and consequently some smearing in the gel, and thus slight cross-contamination of the DNA fragments.

The spoIIIB locus is close to several other spo loci (Piggot, 1973; Piggot \& Coote, 1976); therefore, it was worth checking if the phage DNA would transform to $\mathrm{Spo}^{+}$any strains harbouring spo mutations close to spoIIIB. None of the strains listed in Table 1 having mutations in the spoIIIA, spoIVB or spoOA loci was transformed to $\mathrm{Spo}^{+}$by $\phi 105 \mathrm{~d} s p o I I I B$ DNA.

The possibility was considered that it was not in fact the spoIIIB gene(s) that had been cloned, but some intergenic suppressor of the mutation in strain 2.3 (spo-2 is the only mutation so far identified in $\operatorname{spoIIIB}$ ). To try to rule out this possibility, two $\mathrm{Spo}^{+}$colonies, obtained by transforming strain 2.3 lys-1 spoIIIB2 with phage $\phi 105 \mathrm{~d}$ spoIIIB DNA, were purified. DNA was 
Table 3. Identification of the EcoRI fragment of phage $\phi 105$ dspoIIIB DNA which contains the spoIIIB2+ gene

Phage DNA (approximately $2 \mu \mathrm{g}$ ) was digested with $E c o$ RI and subjected to agarose gel electrophoresis. The gel was stained with ethidium bromide $\left(1 \mu \mathrm{g} \mathrm{m}^{-1} ; 5 \mathrm{~min}\right)$, visualized on a UV transilluminator, and the partially stained bands were excised. The agarose slices were homogenized in transformation medium $(0.8 \mathrm{ml})$ using a syringe fitted with a 19 guage needle. Competent cells of strain 2.5 rif $^{R}$ spoIIIB $2\left(0 \cdot 1 \mathrm{ml}, 1 \times 10^{8} \mathrm{c}\right.$.f.u. $)$ were then added, and after $90 \mathrm{~min}$ incubation at $37^{\circ} \mathrm{C}$, samples $(0 \cdot 1 \mathrm{ml})$ of culture, suitably diluted, were plated on to Schaeffer's medium in glass Petri plates. After incubating the plates for $18 \mathrm{~h}$ at $37^{\circ} \mathrm{C}$, selection was made for $\mathrm{Spo}^{+}$transformants as described in Methods.

$\begin{array}{lc}\text { EcoRI fragment } & \begin{array}{c}\text { No. of } \\ \mathrm{Spo}^{+} \text {transformants } \mathrm{ml}^{-1}\end{array} \\ \text { 7.5 MDal (B) } & 3.0 \times 10^{3} \\ \text { 5.7 MDal (C) } & 1.2 \times 10^{3} \\ \text { 4.8 MDal (D) } & 2 \cdot 1 \times 10^{3} \\ \text { 3.0 MDal (S) } & 2.6 \times 10^{5} \\ \text { 2.1 MDal (F) } & 2 \cdot 1 \times 10^{2} \\ \text { None (control) } & 1.2 \times 10^{1}\end{array}$

prepared from each of them, and the preparations were used to transform strain MB79 to $\mathrm{Phe}^{+}$. If the spo mutation in the $\mathrm{Spo}^{+}$transformants was merely being suppressed, then among the $\mathrm{Phe}^{+}$transformants there should be congressants carrying the original spoIIIB 2 mutation. Out of 4160 transformants counted, none was $\mathrm{Spo}^{-}$, so it seemed reasonable to conclude that the $\mathrm{Spo}^{+}$ phenotype of the transformants obtained using phage $\phi 105 \mathrm{~d} s p o I I I B$ DNA was due to recombination within the spoIIIB gene(s).

\section{DISCUSSION}

The temperate phages $\rho 11$ and $\phi 105$ have been used to clone both vegetative and early sporulation genes of $B$. subtilis (Kawamura et al., 1980; Iijima et al., 1980; Hirochika et al., 1981). Phage $\phi 105$ is potentially more useful than $\rho 11$ because its DNA is less than half the size of that in $\rho 11$. Consequently, the number of restriction fragments generated by digestion of the DNA with commonly used restriction enzymes is smaller, and it is easier to define and isolate the fragment containing a putative cloned gene (see text).

The recombinant phage $\phi 105 \mathrm{~d} l y s$ first isolated had evidently lost some genes required for synthesis or assembly of the tail components. However, the phage appears to have all the functions necessary for integration, excision and replication of the prophage. A recombinant phage $\phi 105 \mathrm{~d} m e t B$ isolated by Iijima et al. (1980) was also found to lack tails, but this phage existed only in the prophage state together with the wild-type phage in a double lysogen. Both the $\phi 105 \mathrm{~d} l y s$ and $\phi 105 \mathrm{~d}$ spoIIIB phages described in this paper were able to transduce when provided with tails, and the transductants obtained were single lysogens. This was evident from $\mathrm{CsCl}$ gradients of phage obtained from lysogens induced with mitomycin $\mathrm{C}$, since the $\phi 105$ phage band contained only transducing and not plaque-forming phage.

The isolation of $\phi 105 \mathrm{~d} l y s$ and $\phi 105 \mathrm{~d}$ spoIIIB establishes that the lys-1, lys-3 and spoIIIB 2 mutations can be complemented. This occurs in the absence of the recE4 gene product which is known to be required for recombination (Mazza \& Galizzi, 1978) in B. subtilis. The transductants arising from infection with $\phi 105 \mathrm{~d} l y s$ or $\phi 105 \mathrm{~d}$ spoIIIB were diploid for the gene involved because (a) the original mutations were shown to be still present [this excludes the possibility that the observed phenotypes $\left(\mathrm{Lys}^{+}\right.$or Spo $^{+}$) were the result of recombination], (b) the transductants, when induced, gave rise to transducing phages carrying the $l y s^{+}$or $s p o^{+}$genes, (c) all $\mathrm{Lys}^{+}$or $\mathrm{Spo}^{+}$transductants which were tested were immune to superinfection by wild-type $\phi 105$ phage, and (d) no deletion or loss of $l y s^{+}$- or $s p o^{+}$-transducing activity of these recombinant phages has been observed, even after numerous sub-cultures of $r e c E 4^{+}$lysogens. This establishes the phage as a stable vector for clonal and complementation analysis.

Dancer \& Mandelstam (1981) have shown that by fusing protoplasts of $\mathrm{Spo}^{-}$and $\mathrm{Spo}^{+}$strains at about stage III in sporulation, mutations in any of the stage IV loci could be complemented by 
the chromosome carrying the $s p o I V^{+}$allele. However, there was no complementation of mutations in any spoIII or spoV loci. They considered that this lack of complementation could have been due to one of the following: (a) dominance of the spo mutation; (b) a limitation of the method, e.g. the time of fusion (stage III) might have been too late; or (c) a requirement for expression of the spo gene in the forespore compartment (see Lencastre \& Piggot, 1979). The results in this paper show clearly that the spoIIIB 2 mutation can be complemented. This rules out, therefore, dominance of spoIIIB 2 as a reason for the failure to obtain complementation in the fusion experiments (Dancer \& Mandelstam, 1981). Instead, it is more likely that the spoIIIB gene(s) is expressed before the earliest time ( $3 \mathrm{~h}$ after induction of sporulation) at which it is practicable to obtain spores in protoplast fusion experiments. The remaining possibility, that the gene is expressed in the forespore compartment, cannot be ruled out, but is unlikely in view of the results of Lencastre \& Piggot (1979).

This paper further establishes phage $\phi 105$ as a suitable vehicle for the cloning and expression of homologous DNA in B. subtilis. Using this vector it should now be possible to carry out complementation tests on the spoIII or spoV loci which could not be tested in the protoplast fusion system.

We are grateful to Miss Mary Blower for her excellent technical assistance, and to Professor D. J. Tipper for his advice and most helpful discussions in the early stages of this work. This work was supported by the Science and Engineering Research Council.

\section{REFERENCES}

Anagnostopoulos, C. \& Spizizen, J. (1961). Requirements for transformation in Bacillus subtilis. Journal of Bacteriology 81, 741-746.

Birdsell, D. C., Hathaway, G. M. \& Rutberg, L. (1969). Characterization of temperate Bacillus bacteriophage $\phi 105$. Journal of Virology 4, 264-270.

COOTE, J. G. (1972). Sporulation in Bacillus subtilis. Genetic analysis of oligosporogenous mutants. Journal of General Microbiology 71, 17-27.

Dancer, B. N. \& MANDElstaM, J. (1981). Complementation of sporulation mutations in fused protoplasts of Bacillus subtilis. Journal of General Microbiology 123, 17-26.

Dubnau, D., Davidoff-Abelson, R., Scher, B. \& Cirigliano, C. (1973). Fate of transforming deoxyribonucleic acid after uptake by competent Bacillus subtilis: phenotypic characterization of radiationsensitive recombination-deficient mutants. Journal of Bacteriology 114, 273-286.

FLOCK, J. \& RUTBERG, L. (1974). Mature DNA from temperate Bacillus phage $\phi 105$ requires primary recombination to be infectious in transfection. Molecular and General Genetics 131, 301-311.

GlenN, A. R. \& Mandelstam, J. (1971). Sporulation in Bacillus subtilis 168. Comparison of alkaline phosphatase from sporulating and vegetative cells. Biochemical Journal 123, 129-138.

Hirochika, H., Kobayashi, Y., Kawamura, F. \& SAITo, H. (1981). Cloning of sporulation gene spoOB of Bacillus subtilis and its genetic and biochemical analysis. Journal of Bacteriology 146, 494-505.

HoCH, J. A. (1971). Selection of cells transformed to prototrophy for sporulation markers. Journal of Bacteriology 105, 1200-1201.

Hranueli, D., Piggot, P. J. \& Mandelstam, J. (1974). Statistical estimate of the total number of operons specific for Bacillus subtilis sporulation. Journal of Bacteriology 119, 684-690.

IIJima, T., KaWamura, F., Saito, H. \& IKeda, Y. (1980). A specialized transducing phage constructed from Bacillus subtilis phage $\phi 105$. Gene 9, 115126.

JENKINSON, H. F. (1983). Altered arrangement of proteins in the spore coat of a germination mutant of Bacillus subtilis. Journal of General Microbiology 129 , 1945-1958.

Jenkinson, H. F., Kay, D. \& Mandelstam, J. (1980). Temporal dissociation of late events in Bacillus subtilis sporulation from expression of genes that determine them. Journal of Bacteriology 141, 793805

Kawamura, F., Saito, H., Hirochika, H. \& KobayaSHI, Y: (1980). Cloning of sporulation gene, spoOF, in Bacillus subtilis with $\rho 11$ phage vector. Journal of General and Applied Microbiology 26, 345355.

Kawamura, F., S̈himotsu, H., Saito, H., Hirochika, H. \& KobaYASHI, Y. (1981). Cloning of spoO genes with bacteriophage and plasmid vectors in Bacillus subtilis. In Sporulation and Germination, pp. 109-113. Edited by H. S. Levınson, A. L. Sonenshein \& D. L. Tipper. Washington, D.C.: American Society for Microbiology.

Lencastre, H. D. \& Piggot, P. J. (1979). Identification of different sites of expression for spo loci by transformation of Bacillus subtilis. Journal of General Microbiology 114, 377-389.

LiU, H-M., CHAK, K. F. \& Piggot, P. J. (1982). Isolation and characterization of a recombinant plasmid carrying a functional part of the Bacillus subtilis spoIIA locus. Journal of General Microbiology 128 , 2805-2812. 
Lloyd-Jones, G. (1976). Genetics and biochemistry of bacterial sporulation. M.Sc. thesis, University of Oxford, U.K

Losick, R. \& Pero, J. (1981). Cascades of sigma factors. Cell 25, 582-584.

MazzA, G. \& GalizzI, A. (1978). The genetics of DNA replication, repair and recombination in Bacillus subtilis. Microbiologica 1, 111-135.

Moran, C. P., JR, Lang, N., LeGrice, S. F. J., Lee, G., Stephens, M., Sonenshein, A. L., Pero, J. \& LosICK, R. (1982). Nucleotide sequences that signal the initiation of transcription and translation in Bacillus subtilis. Molecular and General Genetics 186, 339-346.

Nester, E. W., Schafer, M. \& Lederberg, J. (1963). Gene linkage in DNA transfer: a cluster of genes concerned with aromatic biosynthesis in Bacillus subtilis. Genetics 48, 529-551.

Okamoto, K., Mudd, J. A., Mangan, J., Huang, W. M., Subbaiah, T. V. \& MarmuR, J. (1968a). Properties of the defective phage of Bacillus subtilis. Journal of Molecular Biology 34, 413-428.

OKamoto, J., MudD, J. A. \& MARMUR, J. (1968b). Conversion of Bacillus subtilis DNA to phage DNA following mitomycin C induction. Journal of Molecular Biology 34, 429-437.

Perkins, J. B., Zarley, C. D. \& Dean, D. H. (1978). Restriction endonuclease mapping of bacteriophage $\phi 105$ and closely related temperate Bacillus subtilis bacteriophages $\rho 10$ and $\rho 14$. Journal of Virology 28, 403-407.

PigGot, P. J. (1973). Mapping of asporogenous mutations of Bacillus subtilis: a minimum estimate of the number of sporulation operons. Journal of Bacteriology 114, 1241-1253.

Piggot, P. J. \& CoOte, J. G. (1976). Genetic aspects of bacterial endospore formation. Bacteriological Reviews 40, 908-962.
Piggot, P. J., MoIr, A. \& Smith, D. A. (1981). Advances in the genetics of Bacillus subtilis differentiation. In Sporulation and Germination, pp. 29-39. Edited by H. S. Levinson, A. L. Sonenshein and D. J. Tipper. Washington, D.C.: American Society for Microbiology.

SADOFF, H. L. (1966). Glucose dehydrogenase-soluble. I. Bacillus cereus. Methods in Enzymology 9, 103-107.

SCHAEFfer, P., IONESCO, H., RYTER, A. \& Balassa, G. (1965). La sporulation de Bacillus subtilis: étude génétique et physiologique. Colloques internationaux $d u$ Centre national de la recherche scientifique 124, $553-563$.

SCher, B. M., LAW, M. F. \& Garro, A. J. (1978). Correlated genetic and EcoRI cleavage map of Bacillus subtilis bacteriophage $\phi 105$ DNA. Journal of Virology 28, 395-402.

Sterlini, J. M. \& Mandelstam, J. (1969). Commitment to sporulation in Bacillus subtilis and its relationship to development of actinomycin resistance. Biochemical Journal 113, 29-37.

WARD, J. B., JR \& Zahler, S. A. (1973). Genetic studies of leucine biosynthesis in Bacillus subtilis. Journal of Bacteriology 116, 719-726.

Yamamoto, K. R., Alberts, B. M., Benzinger, R., LAWHORNE, L. \& TREIBER, G. (1970). Rapid bacteriophage sedimentation in the presence of polyethylene glycol and its application to large-scale virus purification. Virology 40, 734-744.

YounG, M. \& MANDELSTAM, J. (1979). Early events during bacterial endospore formation. Advances in Microbial Physiology 20, 103-162.

YudxIN, M. D. \& TURLEY, L. (1981). Mapping of six mutations in the spoIIA locus of Bacillus subtilis and studies of their response to a nonsense suppressor. Journal of General Microbiology 124, 255-261. 